\title{
P-66
}

\section{Azadirachta Excelsa Ethanolic Leaf Extract and Its Effect Against Some Enteric Pathogens}

\author{
Mohd Fakharul Zaman Raja Yahya*, Nurul Bashirah Ismail and Mohamad Shukri Kamaruddin \\ School of Biology, Faculty of Applied Sciences, UiTM Shah Alam, 40450 Shah Alam, Selangor, Malaysia; \\ E-mail: fakharulzaman@salam.uitm.edu.my
}

Azadirachta excelsa is known as a fast growing native species in Peninsular Malaysia, Sumatra, Borneo, Sulawesi, the Philippines, the Aru Islands and New Guinea. It is also closely related to a Neem plant in the family Meliaceae, namely Azadirachta indica, which is native to tropical India. Despite $A$. excelsa has been traditionally used for diarrhea and dysentery treatment, the scientific study on its inhibitory effect against some enteric pathogens remains not established. To address this issue, gas chromatography mass spectrometry (GCMS) and disc diffusion assay were carried out to determine phytochemical profile and antibacterial activity of $A$. excelsa ethanolic leaf extract respectively. From GCMS analysis, it was found that retention time of chromatographically separated compounds ranged from 27.33 to 38.05 . A major compound detected was Cyclononasiloxane (Retention time: 35.17; Peak area: 37.48). Disc diffusion assay showed that $A$. excelsa ethanolic leaf extract exhibited weak inhibitory effect on Shigella sonnei whilst no inhibitory effect was observed against Escherichia coli and Salmonella typhirium. Diameter of zone of inhibition against $S$. sonnei ranged from $7.8 \pm 0.2$ to $11.8 \pm 0.2 \mathrm{~mm}$. Meanwhile, minimum inhibitory concentration (MIC) and minimum bactericidal concentration (MBC) against $S$. sonnei recorded for $A$. excelsa ethanolic leaf extract were $6.25 \mathrm{mg} / \mathrm{ml}$ and $200 \mathrm{mg} / \mathrm{ml}$ respectively. Taken together, this has led us to suggest that $A$. excelsa ethanolic leaf extract may not effective against enteric pathogens and thus contradicted its traditional use.

Keywords: Azadirachta excelsa, antibacterial activity, Shigenalla Sonnei, enteric infection. 